\title{
Financial Feasibility Study of Oil and Gas Well in Indonesia Case Study: New Oil and Gas Well in PT ABC
}

\author{
Henni Rahman and Sylviana Maya Damayanti
}

\begin{abstract}
PT ABC is a subsidiary of PT PXZ (state owned companies under SKK Migas and PT Pertamina supervision) which is engaged un upstream sector in Indonesia. Seeing the continuing decline in oil and gas reserves in Indonesia and increasing demand, the government request all upstream company to find more source. PT ABC is trying to continue to increase production of oil and gas by opening a new potential project. Revenue sharing will use the gross split method. The purpose of writing this final project is to help PT ABC analyze new projects that will be undertaken. The analysis is carried out by looking at the business situation externally and internally and will be followed by economic analysis and risk analysis to identify the factor that has impact of the project. External analysis shows that the oil and gas industry is still an attractive industry for the government to run and support. However, in its implementation the company have to follow the applicable regulations since oil and gas industry are one of the strategic industries. In addition to funding activities, PT PXZ as the holding company is in a healthy financial condition. The results of economic analysis on the PT ABC project show that this project can be implemented and will generate profits for the company. The NPV to be obtained is USD 46.701.182, the IRR obtained is $17.15 \%$, PBP will last for 5.52 years, and the PI has a value of 1,98. From the risk analysis, there are several factors that affect the economic results of the project, namely the price of oil and gas, the percentage of oil and gas sales, capital expenditure, and the percentage of oil and gas split.
\end{abstract}

Index Terms - Feasibility Study, Gross Split, Monte Carlo Analysis, Oil and Gas, Upstream.

\section{INTRODUCTION}

Indonesia is a rich country in cultural diversity and natural resources. It has 17.500 islands with more than 7.000 are uninhabited. With that huge area, Indonesia has about 260 million population in 2017 and becomes as $4^{\text {th }}$ country with the most population in the world. The growth of Indonesia's population is in range $1,1 \%$ each year and in 2025 , BPS predicted that the population will reach 282-282,4 million [1]. As the population growth, the needs of vehicle growth and led to more oil consumption as the raw material for fossil fuel. From 2014-2018, the amount of oil consumption always exceeds the oil production. Oil production still less than 1 million barrels while the oil consumption is in range of 1,61,8 million barrels [2].

Meanwhile for natural gas, the production always exceeds the consumption rate. But begin in 2019, the consumption is bigger than the production. This occurs as the domestic demand continues to grow along with the increasing number of gas infrastructure. To fulfill the needs, Indonesia do import

Published on December 31, 2020

Henni Rahman, Institut Teknologi Bandung, Indonesia.

(e-mail: henni.rahman ${ }^{\circledR}$ sbm-itb.ac.id) from other company. In addition, the decline rate in oil and gas reserve was affected by wells in Indonesia are quite old and needs a new plan or study to find a new potential well.

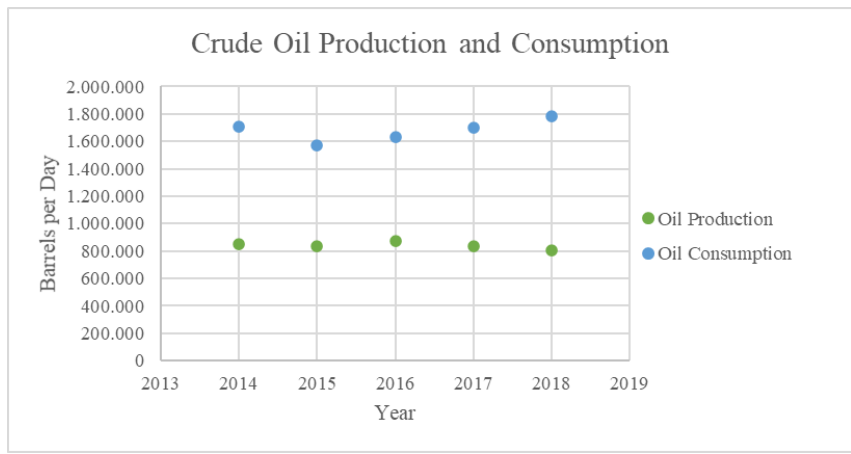

Fig. 1. Crude Oil Production and Consumption in Indonesia.

Based on that condition, government take the decisions to push the upstream industries to level up their exploration and production activities to meet the needs. Hopefully this will help Indonesia to decrease import and add some reserves in this country.

Based on that condition, PT Pertamina (Persero) as the only BUMN (state owned company) that appointed by government of Indonesia to manage oil and gas, ask PT PXZ as their subsidiary in upstream industries to fulfil this target and seek another resource that has potential in the future. PT PXZ is expected to efficiently manage and find new resources of oil and gas in Indonesia with the help of its subsidiaries to do the works in the site. There will be new project to drill and it considered as a new potential well in one of PT PXZ subsidiary field location. The location is in PT ABC working areas and therefore the exploration and production of this well will be managed by PT ABC.

\section{A. Business Issue}

PT ABC will be given the opportunity to do construction of the new potential well. However, it needs a big amount of investment. It covers the exploration activities to know whether there is oil and gas then will be followed by drilling activities. The first thing to be analyzed is the condition of the external environment in oil and gas industry. It should be reviewed as many decisions to make this project executed is based on the regulation and the government's decision. Not to mention the revenue distributed among government and contractor is based on the regulation made by ministry of energy and mineral resources. Afterwards, the financial condition of parent company should be checked as the funding activity is done by PT PXZ. Then, the economic

Sylviana Maya Damayanti, Institut Teknologi Bandung, Indonesia. (e-mail: sylvianamaya@sbm-itb.ac.id) 
feasibility of this project will be calculated to know whether this project has a positive advantage for the company. Lastly, risk assessment will be conducted.

\section{ReSEARCh Methodology}

All data concluded in this study is based on primary and secondary data. Primary data was collected from internal company. Secondary data was earned from financial reports, news, laws, and literatures. External analysis will be using PESTEL/PESTLE analysis. Meanwhile the internal analysis only focus on financial condition of parent company as this factor has direct impact to decision making on funding new investment. To analyze the economic feasibility, this study will use DCF method to obtain NPV, IRR, PBP, and PI. Later, the risk assessment contained sensitivity, scenario, and Monte Carlo analysis will be executed. Based on the risk analysis, solution and recommendation for the company will be made. The solution and recommendation will help the company to prevent the worst case.

\section{EXTERNAL AND INTERNAL ANALYSIS}

\section{A. External Analysis}

External analysis is useful to discover all opportunities and threats that may be happened around the company. This project will use PESTEL analysis is considered appropriate because it involves the aspects that support this project to run. PESTEL or PESTLE is a tool to evaluates 6 factors that can be seen from the perspective of macroeconomic area. PESTEL has a benefit as a framework used by an organization in understanding external influences on a project or new business to be developed [3].

\section{Politic}

Political factors will explain to the certain extent the government decisions will affect the company or the industry. Political factors may include tax policies, fiscal policy, and other regulation that was made to support the actual condition of the country at that time [4]. This industry has a role as the drivers in many areas such as transportation, energy, agriculture, industrial, and chemical production [5].

As the assets of oil and gas belongs to government there are 2 schemes to calculate the revenue sharing between company and government. Originally, there was only one method which is cost recovery. But since 2015, the operating costs itself was way bigger than the revenue of oil and gas. As the revenue was smaller, government feels disadvantaged by the contractors. Began in 2016, ministry of energy and mineral resources proposed a new method called gross split [6].

SKK Migas recorded the realization of oil and gas production ready to sell (lifting oil and gas) is only $90.5 \%$ of the target in 2019. In order to make lifting realization reach the target, there are several attempts made by Ministry of Energy and Mineral Resources.

1. Encourage exploration and production in oil and gas block.

2. Applied the right technology.

3. Working on new methods to find the new resources and reserves.
4. Monitor field development.

5. Do maintenance to improve the reliability of production facilities.

\section{Economic}

Economic environment will discuss the economic effects that occur in countries and industries that affect the company. Th examples are the inflation rate, global oil price movements, economic growth, economic policy, and so on [3]. In Indonesia, oil price is referring as ICP (Indonesia Crude Price). ICP itself use Dated Brent as standard with plus minus from alpha. Alpha was measured by look at the quality of oil, sustainability, and global oil prices [7]. Global oil price is quite fluctuated as a result of supply and demand globally, and OPEC decisions. This applies to all types of oil including Dated Brent oil which is used by Indonesia as a reference. If the price of Brent oil goes up, the ICP will also go up and vice versa as seen in the figure below.

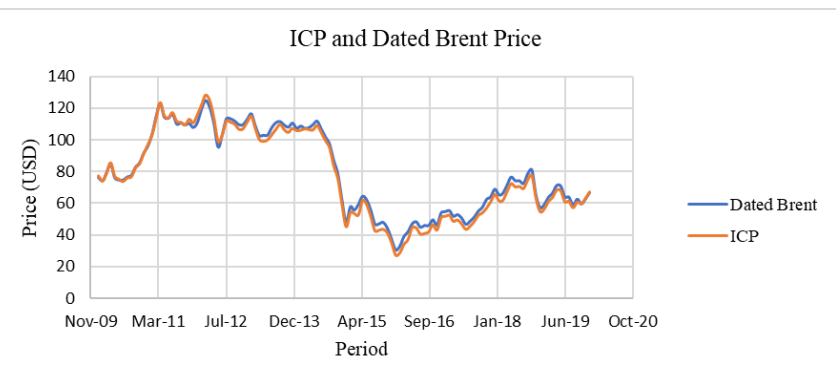

Fig. 2. Dated Brent and ICP Movement.

Natural gas prices tend to be stable for K3S because the selling price will apply following the initial contract. Dwi Soetjipto, the head of SKK Migas said that investment for upstream oil and gas activities in 2019 only reached $81.13 \%$. While the set target is USD 14.79 billion and only USD 12 billion can be realized. Dwi emphasized that the target did not achieve due to the lack of exploration and operation activities by the upstream oil and gas sector [8].

\section{Social}

Sociological factors will include how the industry or company contributes or influences the surrounding environment where a new project or factory will be run. Contribution may consist of the impact of the project on markets, communities, and prosperity of people around location [9]. Based on Law No. 21 of 2001, oil and gas business activities aim to be able to create jobs and be able to boost the welfare and prosperity of the people. SKK Migas as the supervisory agency for the upstream sector is committed to optimizing the use of national labor in every operational activity carried out by the KKKS. This commitment is in line with Law No.13 of 2013 concerning manpower [10].

From 2014 to 2018 , there is a reduction in the number of workers. The decrease in the workforce is related to the downturn in investment in the upstream oil and gas sector, triggered by uncertain oil prices. The government as a facilitator was expected to do something to help players in the upstream oil and gas industry to develop.

\section{Technology}

Technology environment has a definition of how the latest technology can affect the existing condition of the industry. Oil and gas reserves are on a downward trend. Seeing the decreasing trend in energy, it is possible that in the future 
fossil fuels will run out. Therefore, there were some approach by the government to prevent this depletion. Based on Government Regulation No. 79/2014 on National Energy Policy, the target of renewable energy in 2025 is at least $23 \%$ and $31 \%$ in 2050 .

To increase Indonesia's oil production, it can be done by using EOR (Enhanced Oil Recovery) as the most possible method. The other method besides EOR is MEOR. Basically, this has the same technology with EOR with the difference is MEOR use microbial agent in the process. Unluckily, this method still hasn't completely acceptable considering the technical and economic reason [11]. The technology to finding the reserve is still limited. The emerging of renewable energies causing a threat for this project. However, the use of renewable energy is still limited in Indonesia. So, it makes fossil fuels still used and still depends on the condition of oil and gas reserves.

\section{Environment}

Environment is the factors that are determined by surrounding condition or the nature itself. The production process is very vulnerable to polluting the environment and there is the presence of waste generated from the production process. The waste produced is in the form of several types, such as air pollution, liquid waste, and gas waste [12].

Waste gases should not be disposed directly into nature because they are flammable. Regulations on waste gas were based on Minister of Environment Regulation No. 13/2009. Liquid waste was retrieved from the separation of oil and water. For liquid waste, there are regulations prepared by the government, namely the Regulation of the Minister of Environment No. 19/2010.

Oil and gas reserves in Indonesia are predicted to meet the needs only for the next 9.22 and 21.86 years respectively. To anticipate this, the government is trying to increase oil and gas reserves by speeding up the appointment of managers of oil and gas blocks whose contracts have expired and also trying to promote exploration activities for oil and gas potential basins that have not tapped quickly [13].

\section{Legal}

Legal aspects considered some law, regulation, and policies that will affect the industry or company. Such as safety standards, labor laws, government policies, etc. In oil and gas industry, the implementation was based on regulation by government. First is Regulation of the Minister of Energy and Mineral Resources No. 02 of 2008 concerning Implementation of the Obligation to Fulfil Domestic Oil and Gas Needs by Cooperation Contract Contractors.

Second, Regulation of the Minister of Energy and Mineral Resources of the Republic of Indonesia Number 15 of 2018 concerning Post-Operational Activities in the Upstream Oil and Gas Business Activities. This regulation aims to provide guidelines and ensure the implementation of post-operation activities in upstream oil and gas business.

Regarding profit sharing activities (gross split), regulated in the Regulation of the Minister of Energy and Mineral Resources No. 08 of 2017. The regulation has changed to Regulation of the Minister of Energy and Mineral Resources of Republic of Indonesia No. 20 of 2019. It contains which various components must be considered.

\section{B. Internal Analysis}

To carry out an internal analysis of a company, it can be done by looking at resources that are tangible (visible) and intangible (invisible). Internal analysis can check whether the current condition of the company can support the company's plan whether to make a new project or conduct a new business [14]. Tangible resources are resources that can be seen and can be calculated. Tangible resources have 4 categories: financial, organizational, physical, and technological. Although there are several categories in tangible resources, but the main factor that will affect the decision making in making new investment is financial resources.

PT PXZ financial indicators' will be used because PT PXZ will do the investment funding as the parent company for every project that will be carried out by PT PXZ's subsidiary. The calculated financial ratio will be based on the Guidelines issued by PT Pertamina to measure the financial soundness of its subsidiaries [15].

Based on the analysis above, the company's financial condition is in a healthy condition in the past 5 years. It can be concluded that this company is capable of carrying out various investment activities. And able to support the new investment done by its subsidiary.

\begin{tabular}{|c|c|c|c|c|c|c|c|c|c|c|}
\hline Indicators & 2015 & Score & 2016 & Score & 2017 & Score & 2018 & Score & 2019 & Score \\
\hline \multicolumn{11}{|c|}{ Profitability } \\
\hline $\operatorname{ROE}(\%)$ & 12,0 & 14,0 & 9,9 & 10 & 11,9 & 14,0 & 19,0 & 20,0 & 20,7 & 20,0 \\
\hline ROI (\%) & 48,4 & 15,0 & 38,7 & 15 & 42,6 & 15,0 & 58,2 & 15,0 & 48,9 & 15,0 \\
\hline OPM (\%) & 24,1 & 2,5 & 16,5 & 2 & 17,3 & 2,0 & 40,3 & 3,0 & 35,7 & 3,0 \\
\hline NPM (\%) & 11,5 & 2,0 & 12,5 & 2 & 12,5 & 2,0 & 18,9 & 2,5 & 22,1 & 3,0 \\
\hline \multicolumn{11}{|c|}{ Liquidity } \\
\hline Cash Ratio (\%) & 43,3 & 5,0 & 26,9 & 4 & 22,6 & 3,0 & 46,6 & 5,0 & 42,1 & 5,0 \\
\hline Current Ratio (\%) & 45,9 & 0,0 & 66,0 & 2 & 56,9 & 1,0 & 114,2 & 4,0 & 169 & 5,0 \\
\hline \multicolumn{11}{|c|}{ Efficiency } \\
\hline Collection Periods (days) & 24,7 & 3,0 & 29,8 & 3 & 32,6 & 3,0 & 24,7 & 3,0 & 65,4 & 2,5 \\
\hline ITO (days) & 21,6 & 3,0 & 23,7 & 3 & 19,5 & 3,0 & 14,5 & 3,0 & 15,7 & 3,0 \\
\hline TATO $(\%)$ & 101,9 & 2,5 & 79,0 & 2 & 96,7 & 2,5 & 102,8 & 2,5 & 94,5 & 2,5 \\
\hline \multicolumn{11}{|c|}{ Solvability } \\
\hline ETTA $(\%)$ & 33,8 & 7 & 39,5 & 7 & 43,3 & 7,0 & 54,3 & 6,0 & 55,2 & 6,0 \\
\hline Total Score & \multicolumn{2}{|c|}{54,0} & \multicolumn{2}{|c|}{50,0} & \multicolumn{2}{|c|}{52,5} & \multicolumn{2}{|c|}{64,0} & \multicolumn{2}{|c|}{65,0} \\
\hline Total Score (Proportional) & \multicolumn{2}{|c|}{56,4} & \multicolumn{2}{|c|}{52,2} & \multicolumn{2}{|c|}{54,9} & \multicolumn{2}{|c|}{66,9} & \multicolumn{2}{|c|}{67,9} \\
\hline Qualification & \multicolumn{2}{|c|}{ Health } & \multicolumn{2}{|c|}{ Health } & \multicolumn{2}{|c|}{ Health } & \multicolumn{2}{|c|}{ Health } & \multicolumn{2}{|c|}{ Health } \\
\hline
\end{tabular}




\section{ECONOMIC ANALYSIS}

To conduct a valuation, 3 methods can be used such as namely discounted cash flow, relative valuation, and contingent claim valuation. The discounted cash flow method was chosen because this approach is the easiest way to use for firms that have positive cash flow and can be estimated/estimated for the future. The discounted cash flow model is a method that calculates the value of our investment in the future compared to the present by using a discount rate. DCF is the most popular method to use [16].

\section{A. Assumptions}

To calculate the economic valuation of the project, there will be several assumptions to be used, such as:

1. PSC policy will adopt the gross split.

2. Tax rate $25 \%$.

3. Gas price will be USD 6/MMBTU.

4. Projection of oil prices will be using exponential smoothing with $\alpha=0,9$.

5. Quantity sold for oil and gas is $100 \%$.

6. Base split oil and gas will be $43 \%$ and $48 \%$ for contractor.

7. Variable split of oil and gas will be $23,5 \%$ meanwhile progressive split will have slight change every year due to the cumulative production level.

8. This project will have a production life of 12 years with drilling activities occurred for the first 5 years.

9. Investment cost of this project is USD 63.966.281 an obtained from the PPRM department.

The revenue projection based on those assumptions will be shown in the Table 2 and 3 below.

\section{B. Operating Expenditure}

There are 4 components of operating expenditure in this project. The data was obtained from the company's internal data. These 4 components can be seen in the points below.

1. ASR (Abandonment and Site Restoration).

2. Abandonment and Site Restoration is activities for the permanent closer of wells, terminate operations, and deprive production and additional facilities to be operated again including unloading the facilities permanently as well as carrying out environmental restoration. The assumption for ASR cost will be $7 \%$ from the total capex.

3. PBB (Pajak Bumi dan Bangunan/Property Tax).

4. Assumption for PBB funding will be $3 \%$ from the overall PBB payment for block and will be escalated based on inflation rate which is $3 \%$.

5. Operation and Maintenance.

6. The assumptions used for the first-year running will be based on the assumptions on previous projects with similar circumstances and will use an inflation rate of $3 \%$ for escalation.

7. Rent Asset.

8. Regarding activities in the block, there will be rental fees paid to the state because the oil and gas industry is a strategic industry for the state and all-natural wealth belongs to the state.

The amount of operating expenditure will be seen in the Table 4 below.
TABLE 2: REVENUE PROJECTION OF OIL

\begin{tabular}{cccccc}
\hline \hline YoY & $\begin{array}{c}\text { Oil } \\
\text { Production } \\
\text { (MBOPD) }\end{array}$ & $\begin{array}{c}\text { Oil } \\
\text { Price } \\
\text { (USD) }\end{array}$ & $\begin{array}{c}\text { Oil Revenue } \\
\text { Before Split } \\
\text { (USD) }\end{array}$ & $\begin{array}{c}\text { Oil } \\
\text { Split }\end{array}$ & $\begin{array}{c}\text { Oil Revenue } \\
\text { After Split } \\
\text { (USD) }\end{array}$ \\
\hline 2020 & - & - & - & - & - \\
2021 & - & - & - & - & - \\
2022 & - & - & - & - & - \\
2023 & - & - & - & - & - \\
2024 & 440,426 & 54,90 & 8.825 .772 & $83,60 \%$ & 7.378 .493 \\
2025 & 537,168 & 54,95 & 10.773 .639 & $83,29 \%$ & 8.973 .753 \\
2026 & 420,500 & 57,73 & 8.860 .763 & $82,56 \%$ & 7.315 .118 \\
2027 & 388,100 & 59,26 & 8.394 .690 & $82,16 \%$ & 6.896 .819 \\
2028 & 360,284 & 57,94 & 7.619 .919 & $82,37 \%$ & 6.276 .476 \\
2029 & 338,398 & 56,96 & 7.035 .121 & $82,40 \%$ & 5.797 .266 \\
2030 & 324,758 & 57,37 & 6.800 .283 & $82,73 \%$ & 5.625 .902 \\
2031 & 312,697 & 57,85 & 6.602 .975 & $82,59 \%$ & 5.453 .080 \\
2032 & 307,134 & 57,88 & 6.488 .223 & $82,47 \%$ & 5.350 .652 \\
2033 & 304,347 & 57,60 & 6.398 .584 & $82,45 \%$ & 5.275 .778 \\
2034 & 301,461 & 57,53 & 6.330 .338 & $82,50 \%$ & 5.222 .624 \\
2035 & 298,275 & 57,65 & 6.275 .931 & $82,52 \%$ & 5.179 .120 \\
\hline \hline
\end{tabular}

TABLE 3: REVENUE PROJECTION OF GAS

\begin{tabular}{cccccc} 
YoY & $\begin{array}{c}\text { Gas } \\
\text { Production } \\
\text { (MMBTU) }\end{array}$ & $\begin{array}{c}\text { Gas } \\
\text { Price } \\
\text { (USD) }\end{array}$ & $\begin{array}{c}\text { Gas Revenue } \\
\text { Before Split } \\
\text { (USD) }\end{array}$ & $\begin{array}{c}\text { Gas } \\
\text { Split }\end{array}$ & $\begin{array}{c}\text { Gas Revenue } \\
\text { After Split } \\
\text { (USD) }\end{array}$ \\
\hline 2020 & - & - & - & - & - \\
2021 & - & - & - & - & - \\
2022 & - & - & - & - & - \\
2023 & - & - & - & - & - \\
2024 & 4.773 .407 & 6 & 28.640 .439 & $84 \%$ & 24.057 .969 \\
2025 & 5.353 .654 & 6 & 32.121 .923 & $84 \%$ & 26.982 .415 \\
2026 & 3.706 .679 & 6 & 22.240 .071 & $84 \%$ & 18.681 .660 \\
2027 & 2.820 .928 & 6 & 16.925 .567 & $84 \%$ & 14.217 .477 \\
2028 & 2.085 .706 & 6 & 12.514 .239 & $84 \%$ & 10.511 .961 \\
2029 & 1.544 .993 & 6 & 9.269 .957 & $84 \%$ & 7.786 .764 \\
2030 & 1.676 .484 & 6 & 10.058 .905 & $84 \%$ & 8.449 .480 \\
2031 & 2.149 .172 & 6 & 12.895 .031 & $84 \%$ & 10.831 .826 \\
2032 & 2.076 .137 & 6 & 12.456 .825 & $84 \%$ & 10.463 .733 \\
2033 & 2.018 .088 & 6 & 12.108 .527 & $84 \%$ & 10.171 .162 \\
2034 & 1.900 .598 & 6 & 11.403 .588 & $84 \%$ & 9.579 .014 \\
2035 & 1.502 .517 & 6 & 9.015 .102 & $84 \%$ & 7.572 .685 \\
\hline \hline
\end{tabular}

TABLE 4: OPERATING EXPENDITURE PROJECTION

\begin{tabular}{ccccc}
\hline Year & $\begin{array}{c}\text { Operation } \\
\text { and } \\
\text { Maintenance }\end{array}$ & $\begin{array}{c}\text { Property } \\
\text { Tax }\end{array}$ & $\begin{array}{c}\text { Abandonment } \\
\text { and Site } \\
\text { Restoration }\end{array}$ & Rent Asset \\
\hline 2024 & $\$ 2.405 .058$ & $\$ 324.134$ & $\$ 373.137$ & $\$ 189.931$ \\
2025 & $\$ 2.477 .210$ & $\$ 333.858$ & $\$ 373.137$ & $\$ 189.931$ \\
2026 & $\$ 2.551 .526$ & $\$ 343.873$ & $\$ 373.137$ & $\$ 189.931$ \\
2027 & $\$ 2.628 .072$ & $\$ 354.189$ & $\$ 373.137$ & $\$ 189.931$ \\
2028 & $\$ 2.706 .914$ & $\$ 364.815$ & $\$ 373.137$ & $\$ 189.931$ \\
2029 & $\$ 2.788 .121$ & $\$ 375.760$ & $\$ 373.137$ & $\$ 189.931$ \\
2030 & $\$ 2.871 .765$ & $\$ 387.032$ & $\$ 373.137$ & $\$ 189.931$ \\
2031 & $\$ 2.957 .918$ & $\$ 398.643$ & $\$ 373.137$ & $\$ 189.931$ \\
2032 & $\$ 3.046 .656$ & $\$ 410.603$ & $\$ 373.137$ & $\$ 189.931$ \\
2033 & $\$ 3.138 .055$ & $\$ 422.921$ & $\$ 373.137$ & $\$ 189.931$ \\
2034 & $\$ 3.232 .197$ & $\$ 435.608$ & $\$ 373.137$ & $\$ 189.931$ \\
2035 & $\$ 3.329 .163$ & $\$ 448.677$ & $\$ 373.137$ & $\$ 189.931$ \\
\hline \hline
\end{tabular}

\section{Income Statement Projection}

After doing the calculation of revenue (after gross split), operating expenditure, depreciation, tax, and interest expense then the net profit for contractor will be obtained. Depreciation will be used declining balance method based on Government Regulation no 27 year 2017. Below is the projection of income statement. 


\begin{tabular}{|c|c|c|c|c|c|c|c|}
\hline Year & Revenue (USD) & Expenses (USD) & EBITDA (USD) & $\begin{array}{l}\text { Depreciation } \\
\text { (USD) }\end{array}$ & $\begin{array}{c}\text { Interest Expense } \\
\text { (USD) }\end{array}$ & $\begin{array}{c}\text { Tax Expense } \\
\text { (USD) }\end{array}$ & EAT (USD) \\
\hline 2021 & - & - & - & - & 29.970 & - & $(29.970)$ \\
\hline 2022 & - & - & - & - & 31.799 & - & $(31.799)$ \\
\hline 2023 & - & - & - & - & 213.533 & - & $(213.533)$ \\
\hline 2024 & 31.473 .785 & 4.003 .947 & 27.469 .838 & 5.896 .559 & 1.057 .351 & 5.128 .982 & 15.386 .946 \\
\hline 2025 & 36.033 .646 & 4.107 .173 & 31.926 .473 & 14.517 .430 & 1.020 .000 & 4.097 .261 & 12.291 .782 \\
\hline 2026 & 26.064 .196 & 4.213 .496 & 21.850 .700 & 10.888 .073 & 925.306 & 2.509 .330 & 7.527 .991 \\
\hline 2027 & 21.179 .595 & 4.323 .009 & 16.856 .586 & 8.166 .055 & 825.716 & 1.966 .204 & 5.898 .612 \\
\hline 2028 & 16.856 .599 & 4.435 .807 & 12.420 .791 & 6.124 .541 & 720.977 & 1.393 .818 & 4.181 .455 \\
\hline 2029 & 13.661 .837 & 4.551 .990 & 9.109 .847 & 4.593 .406 & 610.823 & 976.405 & 2.929 .214 \\
\hline 2030 & 14.121 .449 & 4.671 .657 & 9.449 .792 & 3.445 .054 & 494.974 & 1.377 .441 & 4.132 .323 \\
\hline 2031 & 16.331 .236 & 4.794 .915 & 11.536 .321 & 2.583 .791 & - & 2.144 .849 & 6.807 .681 \\
\hline 2032 & 15.867 .176 & 4.921 .870 & 10.945 .306 & 1.937 .843 & - & 2.190 .616 & 6.816 .847 \\
\hline 2033 & 15.504 .382 & 5.052 .634 & 10.451 .747 & 1.453 .382 & - & 2.222 .032 & 6.776 .333 \\
\hline 2035 & 12.802 .955 & 5.326 .049 & 7.476 .906 & 817.528 & - & 1.709 .982 & 4.949 .396 \\
\hline
\end{tabular}

\section{Capital Structure}

Capital structure is a combination of corporate debt and equity in financing activities for investment. The components contained in the capital structure are divided into 3, particularly the cost of debt, the cost of equity, and the cost of capital (WACC).

\section{Cost of Debt}

Cost of debt is a funding activity obtained from long-term loans. These long-term loans can be in the form of loans through banks, shares, crowdfunding, donations, and government grants [17]. The interest rate was obtained from PT PXZ financial report.

$$
\begin{aligned}
& r_{i}=r_{d} \times(1-T) \\
& r_{i}=5.17 \% \times(1-0.25)=3.88 \%
\end{aligned}
$$

\section{Cost of Equity}

The CAPM method will be adopted to calculate the cost of equity. The reason for using this method is that this company as well as parent company have not gone public so the dividend discount model method cannot be applied to determine the value of its cost equity. CAPM method is also useful for helping investors see the level of risk in the project, whether or not it is following their expectations. This risk is represented by symbol $\beta$ [18]. The value of $\beta$ varies, if $\beta>1$ then the company is very volatile (risk is quite large) whereas if $\beta<1$ then the risk is not too big and the company is less volatile than market movement [19]. The following shows a description of the assumptions used in calculating the cost of equity using CAPM.

- Data on market return will be based on historical data of JKSE in 10 years (2010-2019) as the average of market movement in Indonesia.

- Beta number will be used the average historical data of Elnusa and Medco (same business line) with amount of 1.31.

- Risk free rate of return will be used the historical data from IBPA 10 years government bond which is $7.454 \%$.

Based on those assumptions, the calculation of cost of equity will be shown below.

$$
\begin{aligned}
& \mathrm{R}_{\mathrm{s}}=\mathrm{R}_{\mathrm{f}}+\left[\beta \times\left(\mathrm{r}_{\mathrm{m}}-\mathrm{R}_{\mathrm{F}}\right)\right] \\
& \mathrm{R}_{\mathrm{s}}=7.454 \%+[1.31 \times(9.38 \%-7.454 \%)]=13.32 \%
\end{aligned}
$$

\section{Cost of Capital}

WACC or $\mathrm{r}_{\mathrm{a}}$ is the weighted average of the firm's capital structure such as cost of equity and cost of debt. Cost of equity and cost of debt has been calculated by using CAPM method as mentioned above. WACC will represents the expected return on portfolio from all the firm's debt and equity [20]. The assumption used in calculating WACC are seen as follows.

1. Company's long-term debt are taken from PT PXZ's financial report.

2. Tax rate will be $25 \%$.

Based on two assumptions above, the WACC will be defined.

$$
\begin{aligned}
& r_{a}=\left(w_{i} \times r_{i}\right)+\left(w_{p} \times r_{p}\right)+\left(w_{s} \times r_{r} \text { or } n\right. \\
& r_{a}=(34,14 \% \times 3,88 \%)+(65,86 \% \times 13.32 \%) \\
& r_{a}=10.09 \%
\end{aligned}
$$

The result of WACC is $10.32 \%$. This amount is consider approved as the good WACC has a small amount. This is because if the WACC result is high, it will indicate that the risk to be faced by the company related to this project is very large.

\section{E. Feasibility Analysis}

Capital budgeting is the essential decision to figure out which project can maximize the shareholder's value. There are 3 methods to evaluate an investment project which is net present value (NPV), internal rate of return (IRR), and payback period (PBP) [21]. The other calculation for capital budgeting is profitability index (PI).

NPV has an approach of discounting all future cash flows (in and out) resulting from the project with a certain discount rate and will be sum together. A project will be accepted if the value of NPV is greater than zero because it means the project will be profitable for the company [22].

IRR is the discount rate that will make the amount of net present value (NPV) of an investment becomes zero. IRR will estimate the rate of return a company can get from a project they invest and will be receive the given cashflow. The higher the IRR, the more desirable it is to carry an investment. A project will be accepted if the IRR's value is greater than the cost of capital. 
PBP is the time needed for a project to gain a profit or to cover the investment cost in the beginning. A project can be accepted if the value of PBP is shorter than the project's life [23]. Meanwhile PI is simply the evaluation of the profitability of an investment. The rule of thumb of PI is if the value is greater than 1 , the decision to invest in a project will be accepted. PI $>1$ will correlate to NPV greater than 0 [24]. The result of NPV, IRR, PBP, and PI for this project is seen below.

\begin{tabular}{lr} 
TABLE 6: FINANCIAL FEASIBILITY ANALYSIS \\
\hline \hline Payback Period & 5,52 \\
Discounted Payback Period & 6,31 \\
Net Present Value & $\$ 46.701 .182$ \\
Profitability Index & 1,98 \\
IRR & $17,15 \%$ \\
\hline \hline
\end{tabular}

Each element from the table above will be analyze one by one.

1. NPV.

2. From the data above, it can be seen that this project generated NPV of $\$ 46.701 .182$. The project is approved as the NPV value exceed 0 and has a positive value.

3. Payback Period and Discounted Payback Period.

4. In payback period and discounted payback period analysis, this project takes 5,52 and 6,31 years respectively. This amount can be rounded up to 7 years. In this category the project also passed as the payback period and discounted payback period term still below the asset's life which is 12 years.

5. Profitability Index (PI).

6. For the profitability index, this project has a value of 1.98. This amount is considered acceptable as the minimum number of PI for an investment or project to run is 1. With PI number is above 1 , then the present value of future cash inflow of this project is greater than the initial investment.

7. Internal Rate of Return (IRR).

8. This project has IRR of $17.15 \%$. This is also considered approve as the IRR exceed the discount rate which is $10.09 \%$. With IRR > discount rate, it can be assumed that this project will have surplus earnings or profitable.

Based on the components above, this project can be conducted as it has successfully fulfilled all the requirements needed for investment whether it is profitable for companies and investors. However, further analysis is needed to know if the condition in the future is different from the current one.

\section{F. Sensitivity Analysis}

Sensitivity analysis is a method to know that uncertainty of various input could affect the output of a model. This analysis is done by adjust some variables. After that, which variable has a great impact towards the result of the model will be discovered. With sensitivity analysis, the most-risky variable could be found [25].

To know which variable that has a greatest influence toward the NPV, a tornado chart will be shown below.

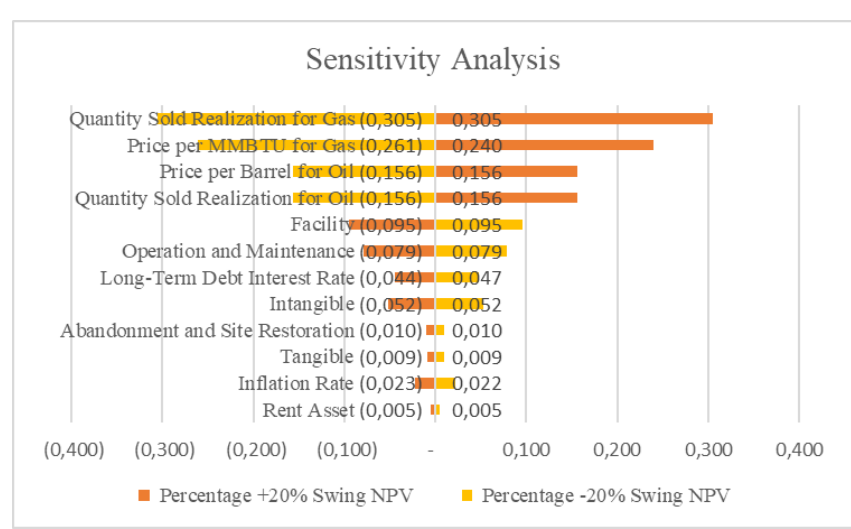

Fig. 3. Tornado Chart.

There are several variables that will have a huge impact to the project's output. It will be observed further in scenario analysis.

\section{G. Scenario Analysis}

Scenario analysis is simply an approach to know possible dependences between two or more input simultaneously. This method can show the possible relationship among variables [26]. The variables that will be used for the assumptions for the scenario analysis are those that have a swing above $40 \%$ in sensitivity analysis. However, some variables such as quantity sold oil and gas, oil and gas price, and capital expenditure will be included as the movement sometimes fluctuated and depends on the condition at that time [27]. This table below will show the change between NPV, IRR, PBP, and PI after the scenario in each condition was done at the same time.

TABLE 7: SCENARIO ANALYSIS

\begin{tabular}{cccc}
\hline \hline Input & Worst Case & Base Case & Best Case \\
\hline Facility & $\$ 56.532 .062$ & $\$ 40.380 .044$ & $\$ 32.304 .035$ \\
Oil Sold & $65 \%$ & $100 \%$ & $110 \%$ \\
Oil Price & $75 \%$ & $100 \%$ & $130 \%$ \\
Gas Price & $\$ 2$ & $\$ 6$ & $\$ 8$ \\
Gas Sold & $65 \%$ & $100 \%$ & $110 \%$ \\
NPV & $\$(42.769 .776)$ & $\$ 46.701 .182$ & $\$ 91.616 .679$ \\
IRR & $-2,48 \%$ & $17,15 \%$ & $22,41 \%$ \\
PI & $(1,81)$ & 1,98 & 3,88 \\
PBP & 15,11 & 5,52 & 4,76 \\
\hline \hline
\end{tabular}

From the table before, if the analysis is running in worst case then the NPV will be negative which is \$ (42.769.776). The IRR itself will have a number below discount rate which is $(2.48 \%)$. PI will have a value of (1.81) and the payback period will have 15.11 years or can be rounded up to 16 years. If the situation is much like the worst scenario, then this project couldn't be executed as most of the capital budgeting elements do not pass the requirements. Moving on to the best case, the resulting NPV will have \$91.616.679 with an IRR of $22.41 \%$, PI of 3.88 , and a payback period of 4.76 years or 5 years.

\section{H. Monte Carlo Simulation}

Monte Carlo Simulation or MCS is an approach by using a random sampling to automate the process to recalculate model in multiple times as a certain input are varied simultaneously (randomly). The use of this method is a generalization of scenario modelling, in which many scenarios are generated automatically using random sampling of probability distributions. Monte Carlo utilizes statistical 
tools to mathematically model a real-life system or process and then estimates the probability of possible outcome [26].

After knowing in the worst, base, and best case, it is necessary to notice how much probability of the project to be failed or make the company loss can be known. In the calculation, it will use 1000 iterations. The table and figures below will illustrate the analysis results from the Monte Carlo Simulation.

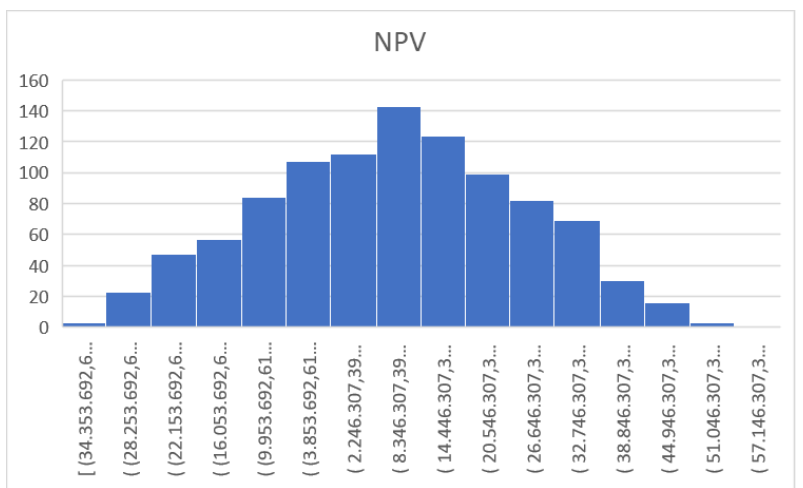

Fig. 4. Monte Carlo Simulation for NPV.

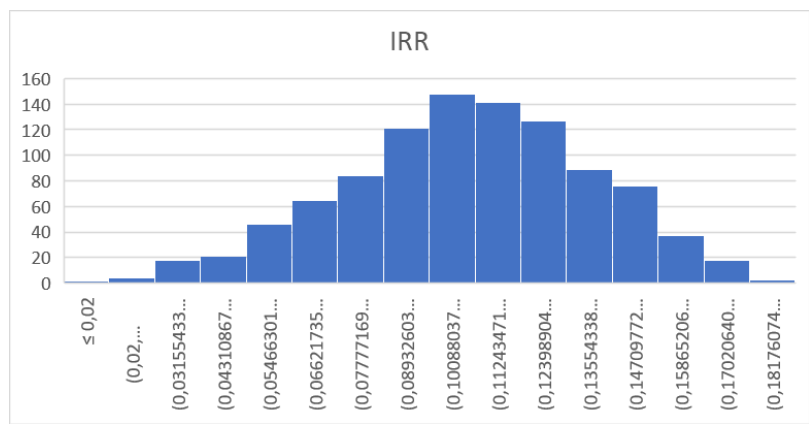

Fig. 5. Monte Carlo Simulation for IRR.

The data above were distributed normally. Skewness and kurtosis for NPV, IRR, and PI still in the range of -2 and +2 and the kurtosis value is between -7 to +7 . So, it can be concluded that the simulation is valid and can be approved [28].The payback period analysis was not performed because from the results of the scenario analysis, even the worst-case was still under the age of the asset. Although the probability level for NPV, IRR, and PI is quite small, there is still a possibility that this will occur when running the project. Therefore, it is necessary to have mitigation and strategies or recommendations.

\section{SOLUTION AND RECOMMENDATION}

There were several aspects may make this project unfit to run if during the construction process these parameters fall into the worst scenario. The following is a solution and recommendations for sensitive parameters to maintain the economic viability of the project to be implemented.

\section{Capital Expenditure}

Capital expenditure is one of the factors that become a concern for companies when opening a new project. Since the last decade, capital expenditure has skyrocketed because companies tend to continue to carry out production activities and strive for the optimal number of products produced.

The capital expenditure issued by PT ABC will be used for drilling activities as the important phase. In drilling, the capacity of oil and gas can be measured appropriately as the capacity before was assumed by engineer based on the research only. To reduce the capital expenditure cost, these actions can be done.

a. Enforce efficiency on rig installation cost.

Evaluate with R\&D or engineer team in case there's another type of rig that cost less than the actual one.

b. Reduce contingency plan cost.

In usual condition, there is contingency cost that will be add up to the capital expenditure. Usually company the value of contingency cost can be $10-15 \%$ of capital expenditure but if the risk is much higher (extreme offshore drilling) then the cost can be up to $30 \%$.

c. Boost the efficiency in drilling time.

d. Do negotiations with drilling service company. Hopefully by doing negotiation, the cost for drilling can be lower than before by doing agreements [29].

e. Standardization for well construction.

Well standardization can make the cost to build a new well equal and the construction time will be the same.

\section{Quantity Sold for Oil and Gas}

Quantity sold for oil and gas will be combined as a well produce oil, gas, and water simultaneously. However, sometimes several things cause the amount of oil and gas produced cannot reach the target. For example, there is a leak in a well, an accident on a tanker carrying oil, and inadequate technology determination or a less than optimal production process so that the yield of the reaction results is reduced. The oil spill also adds to the company's expenses. For every $1 \mathrm{~L}$ spill, it costs $\$ 300$ for a clean-up. The following are some actions that can be done to minimize this risk.

a. To avoid any environment risk (leaks in well), the key components that should be prepared by the company are complete equipment, good procedure, and worker training.

b. Seek another method with R\&D team whether there's another possibility of new invention to maximize yield rate of oil and gas production.

c. Evaluate the current FPSO, to avoid any accident.

This can be done by looking at the FPSO's structure and design to know if it fits the condition of the product and the sea. Because there were many cases when the FPSO burned as the condition of the FPSO is not good and need maintenance.

d. Maintenance and monitoring to production activity.

3. Prices of Oil

The fluctuating movement of crude oil price is indeed an inevitable condition for companies. The price of petroleum in Indonesia is strongly influenced by the global oil prices. The global oil price itself is influenced by supply and demand, the country's economy globally, policies of Europe countries as well as US, and OPEC policies. These are the things that make PT ABC unable to take preventive actions.

The last thing that can be done to deal with uncertainty conditions regarding the oil prices is fully prepared for the worst scenario. Ex-minister of energy and mineral resources, Archandra Tahar said the last thing for upstream companies to face the sudden decrease in oil price is by doing a contract agreement between producers and consumers. With purchase contracts, upstream companies will still benefit because the 
price of oil sold is fixed and will not be affected by the situation.

\section{Prices of Gas}

The price of gas or natural gas is regulated by the government based on the Regulation of Minister of Energy and Mineral Resources No. 8 of 2020 at USD 6 / MMBTU. The price set is under the contract made between PT ABC and the consumer (industry). Initially, the gas price could reach USD 8-9 / MMBTU. However, due to the lack of national competitiveness, prices were lowered. However, these costs can adjust depending on the transportation costs incurred by the upstream party.

Therefore, to cover the possibility that the price set by the government is getting lower, $\mathrm{PT}$ ABC needs to maximize the level of sales and production of natural gas as the government is also promoting the use of renewable energy such as natural gas for energy generation and fuel. Hopefully if PT ABC can support the good sales of gas, then the government will make the price go up. Not to mention that this project has more gas to be produced than crude oil. If one day the company is given the freedom to set prices or conditions drop to the worst-case scenario, PT ABC needs to negotiate contracts with consumers so that the price set for the contract is not too low because it will last for a long time.

\section{CONCLUSION}

PT PXZ is one of the companies under PT Pertamina (Persero) to carry out exploration and production activities in Indonesia or can be called a company engaged in the upstream part. This project will be carried out by PT ABC because oil and gas reserves are within the scope of PT ABC's operational activities.

By looking at the external analysis, the sustainability of this project is supported by all these aspects. Although with various restrictions that must be followed and obeyed by the contractor. These various restrictions are made by the government because oil and gas are a part of state assets whose existence and use cannot be done carelessly. The company will use gross split method as revenue sharing.

From the internal side of the company, PT PXZ's financial condition was calculated. In the last 5 years, PT PXZ's financial condition has always been in a healthy condition. With the mean score is 59.68. Based on this, it can be concluded that PT PXZ can provide funding for this new project.

For the financial analysis of this project, several important indicators will be seen such as NPV, IRR, PBP, and PI. This project requires an initial investment of USD 63.966.281. The NPV to be obtained by the company is USD 46.701.182. The resulting IRR has a value above the WACC, which is $17.15 \%$. The PI of this project is 1.98 and PBP will last for 6.31 years. Based on all the parameters above, this project can be said to be feasible.

After conducting an economic analysis of the project, a risk analysis will be carried out using sensitivity, scenario, dan Monte Carlo analysis. From sensitivity analysis, there are several variables that will affect the feasibility of this project. The variables are capital expenditure, quantity sold of oil and gas, price of oil and gas, and split percentage of oil and gas.
Move forward, scenario analysis will be done by looking at worst and best case in every variable from the analysis before.

For worst case, the NPV of this project will be USD (42.769.776). meanwhile for IRR is below WACC which is (2.48\%), PI will have value of (1.81), and PBP will last for 15.11 years. And for best case, the NPV will be USD 91.616.679, IRR number will be above WACC which is $22.41 \%$, PI will have value of 3.88 and the PBP will be 4.76 years. The project has a possibility of being non feasible based on the result on worst case. With Monte Carlo, the probability NPV being below 0 is $26.68 \%$, the IRR will have probability below WACC which is $33.6 \%$.

To avoid conditions above, there were some solutions and recommendations for the company. Such as doing efficiency in capital expenditure part, evaluate current condition of the company (starting from the training until the equipment), do negotiations with the parties involved, and encourage R\&D team to explore another invention or possible approach for maximize the oil and gas production.

\section{REFERENCES}

[1] BPS, "Sensus Penduduk," BPS, Jakarta, 2015.

[2] BP Global Company, "Statistic Review of World Energy," BP Global Company, London, 2019.

[3] N. Rastogi and M. Trivedi, "PESTLE Technique - A Tool to Identify External Risks in Construction Projects," International Research Journal of Engineering and Technology, pp. 384-388, 2016.

[4] S. W. Yudha, B. Tjahjono and A. Kolios, "A PESTLE Policy Mapping and Stakeholder Analysis of Indonesia's Fossil Fuel Eenergi Industry," Energies, p. 3, 2018.

[5] A. Eleonor, "Pestel Analysis on Petroleum Industry," Bucharest, 2012.

[6] SKK, "Indonesia to Replace Oil Recovery Scheme by Gross Profit Sharing," 2016. [Online]. Available: https://www.indonesiainvestments.com/news/todays-headlines/indonesia-to-replace-oilrecovery-scheme-by-gross-profit-sharing/item7434. [Accessed 1106 2020].

[7] Kementrian Energi dan Sumber Daya Alam, "Peraturan Menteri Energi dan Sumber Daya Mineral Nomor 23 Tahun 2012 tentang Tata Cara Penetapan Metodologi dan Formula Harga Minyak Mentah Indonesia," in Peraturan Menteri, Jakarta, Ministry of Energy and Mineral Resources of Indonesia, 2012.

[8] V. N. Setiawan, "SKK Migas: Realisasi Investasi Hulu Migas Tahun Ini Hanya Rp 168,95 T," 13 November 2019. [Online]. Available: https://katadata.co.id/febrinaiskana/energi/5e9a4c56a04d7/skk-migasrealisasi-investasi-hulu-migas-tahun-ini-hanya-rp-16895-

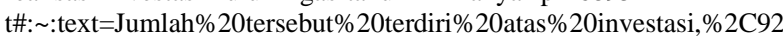
$\% 25 \% 20$ dari\%20tahun\%20sebelumnya.

[9] A. Kolios and G. Read, "A Political, Economic, Social, Technology, Legal and Environmental (PESTLE) Approach for Risk Identification of the Tidal Industry in the United Kingdom," Journal Energies, pp. 5023-2045, 2013.

[10] SKK Migas, "Fokus Tingkatkan Kapasitas Tenaga Kerja Nasional," SKK Migas, Jakarta, 2019.

[11] S. Maudgalya, R. M. Knapp and M. McInerney, "Microbially Enhanced Oil Recovery Technologies: A Review of the Past, Present, and Future," Production and Operation Symposium, 2007.

[12] N. Siahaan, I. Fitri and H. Batih, "Energy in the Power Sector and GHG Emissions: Modeling as an Input to the Formulation of the Next Midterm National Development Plan," Climate Change Policies and Challenges in Indonesia, pp. 173-198, 2016.

[13] P. E. Wicaksono, "Cadangan Minyak Indonesia Hanya Cukup untuk 9 Tahun Lagi," 14 January 2020. [Online]. Available: https://www.liputan6.com/bisnis/read/4155492/cadangan-minyakindonesia-hanya-cukup-untuk-9-tahun-lagi.

[14] M. Hitt, R. D. Ireland and R. E. Hoskisson, Strategic Management: Concepts and Cases: Competitiveness and Globalization, 12e ed., Boston: Cengage Learning, 2016.

[15] Pertamina, Pedoman Penilaian Kinerja Anak Perusahaan, Jakarta: Pertamina, 2019.

[16] L. P. Jennergren, "Continuing Value in Firm Valuation by the Discounted Cash Flow Model," European Journal of Operational Reserach, no. 185, pp. 1548-1563, 2008. 
[17] L. J. Gitman and C. J. Zutter, Principles of Managerial Finance, 14th ed., Harlow: Pearson Education Limited, 2015.

[18] M. Bod'a and M. Kanderova, "Linearity of the Sharpe-Lintner version of the Capital Asset Pricing Model," Social and Behavioral Science, no. 110, p. 1136, 2014.

[19] E. F. Fama and K. R. French, "The Capital Asset Pricing Model: Theory and Evidence," Journal of Economic Perspectives, vol. 18, no. 3, p. 33, 2004.

[20] M. A. Mian and I. V. Pareja, "Applicability of the Classic WACC," Latin American Business Review, vol. 8, no. 2, pp. 24-25, 2007.

[21] N. Hermes, P. Smid and L. Yao, "Capital Budgeting Practices: A Comparative Study of the Netherlands and China," International Business Review, no. 16, pp. 630-654, 2007.

[22] O. Žižlavský, "Net Present Value Approach: Method for Economic Assessment of Innovation Projects," Brno, 2014.

[23] G. Reniers, L. Talarico and N. Paltrinieri, "Cost-Benefit Analysis of Safety Measures," in Dynamic Risk Analysis in the Chemical and Petroleum Industry, M. Convey, Ed., Oxford, Elsevier, 2016, pp. 195205.

[24] M. A. Gurau, "The Use of Profitability Index in Economic Evaluation of Industrial Investment Projects," Bucharest, 2012.

[25] A. Saltelli, S. Tarantola, F. Campolongo and M. Ratto, Sensitivity Analysis in Practice, West Sussex: John Wiley \& Sons, Ltd, 2004.

[26] M. Rees, "Sensitivity and Scneario Analysis, Simulation and Optimisation," in Principal of Financial Modelling, West Sussex, John Wiley \& Sons, Ltd, 2018, pp. 155-160.

[27] M. Gyagri, E. M. Amarfio and S. A. Marfo, "Determinants of Global Pricing of Crude Oil - A Theoretical Review," International Journal of Petroleum and Petrochemical Engineering, pp. 7-15, 2017.

[28] B. M. Bryne, Structural Equation Modeling With AMOS, New Jersey: Lawrence Erlbaum Associates, Inc., Publishers, 2010.

[29] A. Brun, G. Aerts and M. Jerko, "Oil and Gas Practice: How to Achieve 50\% Reduction in Offshore Drilling Costs," McKinsey, Oslo, 2015.

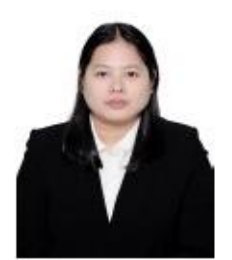

Henni Rahman was born in Tangerang on August 19, 1995. She got her bachelor degree in Chemical Engineering from Parahyangan Catholic Unversity in Bandung. Currently she is pursuing her Master Degree in Business Administration at Institut Teknologi Bandung. She took finance as her major for her master degree.

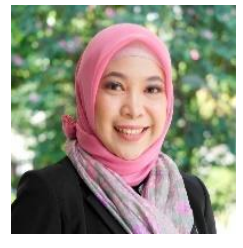

Dr. Sylviana Maya Damayanti, ST., MBA. CFP ${ }^{\circledR}$, CWM ${ }^{\circledR}$., AEPP ${ }^{\circledR}$ earned her Ph.D degree from Faculty of Economics at University of Padjadjaran Bandung in 2015. She obtained her MBA degree from majoring in Management on Institut Teknologi Bandung (ITB) in 2007. And she got her bachelor degree in electrical engineering in Universitas Islam Sultan Agung in

2002.

After she earned her MBA degree, she joined as the lecturer with interest in Business Risks and Finance at School of Business and Management (SBM) ITB. Currently she conducting the Financial Literacy and Inclusion Research Center in SBM ITB partnered with OJK to raise financial literacy and inclusion in Indonesia. 